\title{
Occurrence and Relative Incidence of Viruses Infecting Soybeans in Iran
}

\author{
A. R. Golnaraghi, Plant Protection Department, College of Agriculture and Natural Resources, Science and Re- \\ search Campus, Islamic Azad University, P.O. Box 14515-775, Tehran, Iran; N. Shahraeen, R. Pourrahim, and Sh. \\ Farzadfar, Plant Virology Department, Plant Pests and Diseases Research Institute, P.O. Box 19395-1454, Tehran, \\ Iran; and A. Ghasemi, Oilseed Research and Development Co., P.O. Box 15875-6676, Tehran, Iran
}

\begin{abstract}
Golnaraghi, A. R., Shahraeen, N., Pourrahim, R., Farzadfar, Sh., and Ghasemi, A. 2004. Occurrence and relative incidence of viruses infecting soybeans in Iran. Plant Dis. 88:1069-1074.

A survey was conducted to determine the incidence of Alfalfa mosaic virus (AlMV), Bean common mosaic virus (BCMV), Bean yellow mosaic virus (BYMV), Blackeye cowpea mosaic virus (BlCMV), Cucumber mosaic virus (CMV), Pea enation mosaic virus (PEMV), Peanut mottle virus (PeMoV), Soybean mosaic virus (SMV), Tobacco mosaic virus (TMV), Tobacco ringspot virus (TRSV), Tobacco streak virus (TSV), Tomato ringspot virus (ToRSV), and Tomato spotted wilt virus (TSWV) on soybean (Glycine max) in Iran. Totals of 3,110 random and 1,225 symptomatic leaf samples were collected during the summers of 1999 and 2000 in five provinces of Iran, where commercial soybean is grown, and tested by enzyme-linked immunosorbent assay (ELISA) using specific polyclonal antibodies. Serological diagnoses were confirmed by electron microscopy and host range studies. The highest virus incidence among the surveyed provinces was recorded in Mazandaran (18.6\%), followed by Golestan (15.7\%), Khuzestan (14.2\%), Ardabil (13.9\%), and Lorestan (13.5\%). Incidence of viruses in decreasing order was SMV (13.3\%), TSWV (5.4\%), TRSV (4.2\%), TSV (4.1\%), PEMV (2.9\%), BYMV (2.2\%), ToRSV $(2.1 \%)$, AlMV (1.3\%), BCMV (0.8\%), and CMV (0.6\%). Additionally, $1.5 \%$ of collected leaf samples had positive reactions in ELISA with antiserum to TMV, indicating the possible infection of soybeans in Iran with a Tobamovirus that is related serologically to TMV. Of 195 leaves from plants showing soybean pod set failure syndrome (PSF) in Mazandaran and Lorestan, only 14 (7.2\%) samples had viral infection. No correlation was observed between PSF and presence of the 13 viruses tested, suggesting the involvement of other viruses or factors in this syndrome. To investigate the presence of seed-borne viruses, including SMV, TRSV, ToRSV, and TSV, 7,830 soybean seeds were collected randomly at harvesting time from the major sites of soybean seed production located in Mazandaran and Golestan provinces. According to ELISA analyses of germinated seedlings, 7.1 and $8.9 \%$ of the seed samples from Golestan and Mazandaran provinces, respectively, transmitted either SMV, TRSV, ToRSV, or TSV through seed. We also showed that SMV and other seed transmissible viruses, as well as TSWV, usually are the most prevalent viruses in soybean fields in Iran. In this survey, natural occurrence of AlMV, BCMV, BlCMV, BYMV, CMV, PEMV, PeMoV, and TSWV was reported for the first time on soybeans in Iran.
\end{abstract}

Additional keywords: soybean viruses

Soybean (Glycine max (L.) Merr.) is one of the most important oilseed crops in the world, and its production has suffered from many problems of pests and diseases, including those caused by viral agents. Soybean is susceptible to infection by several viruses, which substantially reduce yield and quality (39). For example, virus diseases are estimated to have reduced U.S. soybean yields by over 760,000 metric tons in 2002 (43). More than 111 viruses or strains, belonging to different virus genera and families, are able to infect soy-

Corresponding author: A. R. Golnaraghi

E-mail: agolnaraghi@yahoo.com

Accepted for publication 4 March 2004.

Publication no. D-2004-0722-01R

(C) 2004 The American Phytopathological Society bean naturally or under experimental conditions (15). Among these viruses, soybean is a natural host for 33 potentially important viruses (39).

As soybean cultivation increases in Iran (88,000 ha in 1999 [9]), occurrence of virus and virus-like diseases can limit production. Investigations of incidence and distribution of soybean viruses are very important in developing diagnostic systems and appropriate control measures. Also, knowledge about which viruses are likely to be most prevalent in a particular region allows farm advisors to guide growers in disease management. There have been a few previous studies on soybean viral diseases and their distribution in Iran. In Golestan and Mazandaran provinces, Tobacco ringspot virus (TRSV), Tobacco streak virus (TSV), and Tomato ringspot virus (ToRSV) were isolated from soybean plants showing pod set failure syndrome
(PSF), which is of great concern to farmers in some seasons. Rahimian et al. (32) found that mechanical inoculation and grafting of the affected plants on soybean caused the same symptoms, but this preliminary finding has not been confirmed. Furthermore, the possible role in this syndrome of other viruses infecting soybeans or mixed infections of them has not been studied yet. Soybean mosaic virus (SMV) has also been reported previously from Iran $(8,20)$.

For these reasons, a survey was conducted to determine the incidence and distribution of different viruses, including Alfalfa mosaic virus (AlMV), Bean common mosaic virus (BCMV), Bean yellow mosaic virus (BYMV), Blackeye cowpea mosaic virus (BlCMV) which is now considered a strain of BCMV $(6,41)$, Cucum ber mosaic virus (CMV), Pea enation mosaic virus (PEMV), Peanut mottle virus (PeMoV), SMV, Tobacco mosaic virus (TMV), TRSV, ToRSV, TSV, and Tomato spotted wilt virus (TSWV), that infect soybeans in Iran. Additionally, possible involvement of the mentioned viruses or mixed infections of them in PSF was tested. Soybean seed-borne viruses, because of their spread by infected seeds, have a great economic and epidemiological importance. In this survey, the prevalence of four seed-transmissible viruses, including SMV, TRSV, ToRSV, and TSV, was studied in soybean seed fields in Golestan and Mazandaran, the two main seed production provinces.

\section{MATERIALS AND METHODS}

Surveys. During the summers of 1999 and 2000, surveys were conducted to identify viruses affecting soybeans in five main soybean cultivation provinces of Iran (Fig. 1). In 1999, 150 symptomatic leaf samples showing mosaic, mottling, yellowing, stunting, chlorosis, and vein or top necrosis, were collected from 18 fields in Golestan and Mazandaran. Additionally, 3,110 soybean leaf samples were collected randomly (before or through flowering stage, 30 to 60 days after planting) from 80 soybean fields located in Ardabil, Golestan, Khuzestan, Lorestan and Mazandaran provinces in $2000(553,709,451,466$, and 931 leaf samples, respectively) (Table $1)$, as well as 880 symptomatic samples. The fields were randomly selected using a predetermined distance criterion, where 
distance between the fields ranged from 5 to $20 \mathrm{~km}$. Two types of leaf samples were collected from each field: 10 to 15 plants exhibiting symptoms of viral disease, and 30 to 50 randomly collected plants regardless of whether they showed symptoms. In addition, 81 and 114 leaves were sampled from soybean plants showing associated symptoms of PSF in eight fields of Lorestan and Mazandaran. The affected soybeans showed short internodes with fewer and deformed pods, having few seeds. In some cases (fields of Lorestan), stem thickness and a high number of flowers and pods in the basal parts of the plants were observed. These plants showed continuous vegetative growth and remained green late in the growing season. Each sample was collected from a different plant. They were immediately placed in plastic bags, transported in cold boxes, and stored at $4^{\circ} \mathrm{C}$ until tested by enzyme-linked immunosorbent assay (ELISA).

Sources of antisera and positive samples. ELISA kits with polyclonal antibodies against AlMV, BYMV, CMV, SMV, TMV, TRSV, and ToRSV were purchased from Sanofi (France); BCMV ELISA kit from Adgen Diagnostic (UK); TSV (As0171, PV-0309) and TSWV (As-0526, As0580, and PV-0526) were kindly provided by S. Winter (DSMZ-Braunschweig, Germany); PEMV positive control and antiserum was produced against an Iranian isolate of PEMV from pea (11); BICMV antiserum and the positive (cowpea isolate) were kindly provided by G. Thottappilly (ITIA, Ibadan, Nigeria), and PeMoV antiserum by J. Chalkey (University of Georgia, Agricultural College Experimental Station, Griffin); and our Iranian isolate from peanut (34) was used as a positive control sample. All of these detection systems were checked for possible crossreactivity of related viruses in the potyvirus and the nepovirus groups.

Serological assays. The double antibody sandwich ELISA (DAS-ELISA) procedure was performed according to the general protocols for each virus and closely followed those developed earlier $(7,22)$. ELISA plates (Nunc Maxisorb, Denmark) were coated with $100 \mu$ of 1:1,000 dilution of related IgGs in carbonate coating buffer ( $15 \mathrm{mM} \mathrm{Na} \mathrm{CO}_{3}, 35$ $\mathrm{mM} \mathrm{NaHCO} 3$, and $5 \mathrm{mM} \mathrm{NaN}_{3}, \mathrm{pH}$ 9.6) and incubated overnight at $4^{\circ} \mathrm{C}$. Samples were extracted in extraction buffer (1:5 wt/vol) $\left(3 \mathrm{mM} \mathrm{KCl}, 3 \mathrm{mM} \mathrm{NaN}_{3}, 8 \mathrm{mM}\right.$ $\mathrm{Na}_{2} \mathrm{HPO}_{4}, 1 \mathrm{mM} \mathrm{NaH} \mathrm{PO}_{4}$, and $0.13 \mathrm{M}$ $\mathrm{NaCl}$ (PBS) containing 2\% polyvinylpyrrolidone (PVP)-24,000 and 0.05\% Tween 20, pH 7.4). Wells were washed four times, at 5-min intervals, with washing buffer (0.05\% Tween 20 in PBS), and $100 \mu \mathrm{l}$ of plant extract was added to each well and incubated overnight at $4^{\circ} \mathrm{C}$. Wells were washed four times with washing buffer; then $100 \mu \mathrm{l}$ of alkaline phosphataseconjugated IgG diluted in conjugate buffer (2\% PVP-24,000, 0.05\% Tween 20, 0.2\% bovine serum albumin [BSA] and $1 \mathrm{mM}$ $\mathrm{MgCl}_{2}$ in PBS, $\mathrm{pH}$ 7.4) was added and incubated $3 \mathrm{~h}$ at $35^{\circ} \mathrm{C}$. Wells were washed four times with washing buffer and incubated in $100 \mu \mathrm{l}$ of substrate $(1 \mathrm{mg} / \mathrm{ml} p$ nitrophenyl phosphate and $3 \mathrm{mM} \mathrm{NaN}_{3}$ in diethanolamine buffer, $\mathrm{pH} 9.8$ ), and absorbance was determined at $405 \mathrm{~nm}$ by an ELISA-reader (Multiscan-334) after 60 min. Samples with absorbance values greater than or equal to three times the average of negative samples were considered infected (positive).

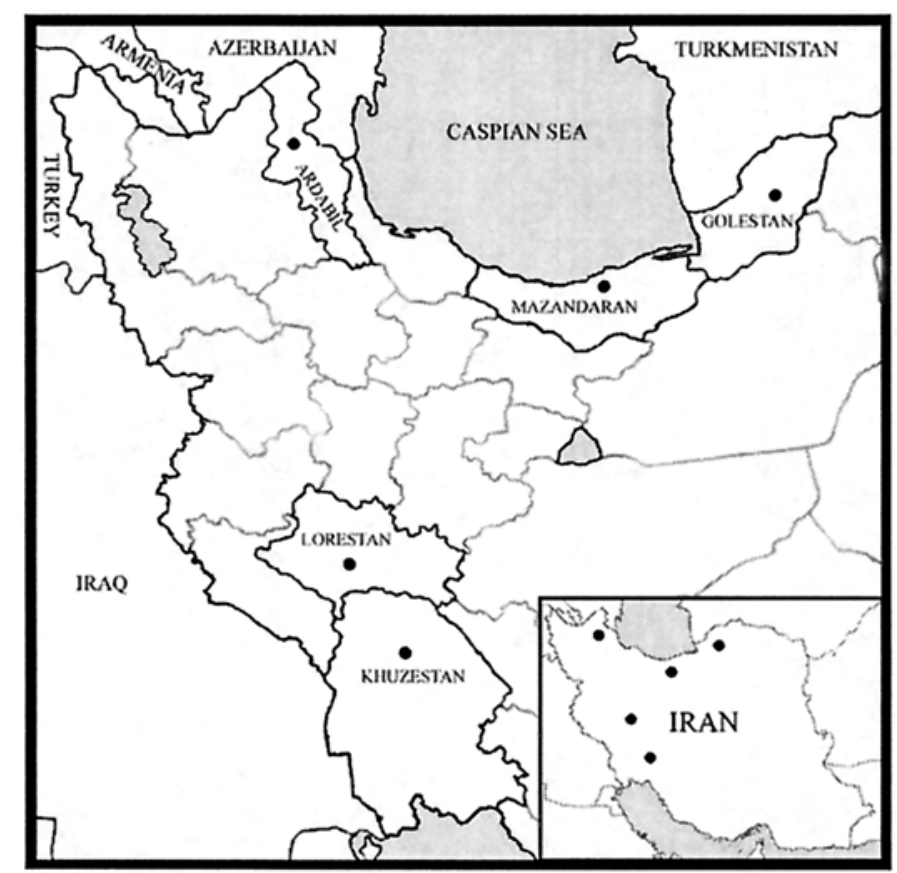

Fig. 1. Map of Iran showing location of surveyed provinces. Courtesy of Farzadfar et al. (10).

Dot-ELISA was only used to check the presence of BlCMV and PeMoV in symptomatic samples, according to procedures described earlier (1). Nitrocellulose membrane $(0.45-\mu \mathrm{m}$ pore size, GIBCO, Grand Island, NY) was washed in Tris-buffered saline (TBS) $(20 \mathrm{mM}$ Tris- $\mathrm{HCl}, 0.5 \mathrm{M}$ $\mathrm{NaCl}, \mathrm{pH} 7.5)$ containing $0.05 \%$ Tween 20 (TBS-T) for $10 \mathrm{~min}$ and dried for $20 \mathrm{~min}$ on filter paper. Each leaf extract $(1 \mathrm{~g}$ per 1 $\mathrm{ml}$ of buffer) was extracted with chloroform to remove chlorophyll, and $5 \mu \mathrm{l}$ was dotted on the membrane; then the membrane was washed in TBS-T for $10 \mathrm{~min}$ and blocked for 1 to $3 \mathrm{~h}$ at room temperature in 2\% BSA in TBS-T. The nitrocellulose membrane was washed twice in TBS$\mathrm{T}$ and incubated in a 1:500 dilution of antiserum in TBS for $1 \mathrm{~h}$, washed and incubated with 1:10,000 dilution of alkaline phosphatase-conjugated goat antirabbit (Sigma Chemical Co., St. Louis, $\mathrm{MO})$ in TBS for $1 \mathrm{~h}$. Color development solution was $0.1 \mathrm{M}$ Tris- $\mathrm{HCl}(\mathrm{pH} 9.5)$ containing $0.33 \mathrm{mg}$ of nitro blue tetrazolium per $\mathrm{ml}$ and $0.17 \mathrm{mg}$ of 5-bromo-4chloro-3-indolyl phosphate $p$-toluidine per $\mathrm{ml}$ prepared just before use. All buffers in this method contained $0.02 \%$ sodium azide as a preservative. Development of bluepurple color in each dotted area was interpreted as an infected sample.

Host range studies. Soybean leaf samples prepared from Mazandaran (the PeMoV isolates collected from Golestan) with positive reaction in ELISA were selected and ground in $0.1 \mathrm{M} \mathrm{Na-phosphate}$ buffer ( $\mathrm{pH} 7.0$ ) containing $0.2 \%$ sodium sulfite as a general inoculation buffer. In host range trials, at least two plants of each species or cultivar from Amaranthaceae, Chenopodiaceae, Fabaceae, and Solanaceae (Table 2) were mechanically inoculated. The tests were repeated at least twice in cases that yielded negative or uncertain results. The plants were kept in a greenhouse with at least $12 \mathrm{~h}$ light, $25 \pm 5^{\circ} \mathrm{C}$, and 50 to $70 \%$ relative humidity, and observed 1 to 3 weeks or longer after inoculation. ELISA was used as well as symptomology to check for presence of related viruses in inoculated plants.

Electron microscopy. To detect virus particles, carbon and Formvar-coated grids were floated on $20 \mu \mathrm{l}$ of each collected field sample (crude extract) for $5 \mathrm{~min}$, washed with 40 drops of distilled water,

Table 1. Numbers of fields surveyed and random samples collected from different provinces of Iran

\begin{tabular}{lccc}
\hline Province & Location & Field & $\begin{array}{c}\text { Leaf } \\
\text { sample }\end{array}$ \\
\hline Ardabil & 3 & 14 & 553 \\
Golestan & 5 & 18 & 709 \\
Khuzestan & 3 & 11 & 451 \\
Lorestan & 3 & 13 & 466 \\
Mazandaran & 11 & 24 & 931 \\
Total & 25 & 80 & 3,110 \\
\hline
\end{tabular}


and negatively stained with 5 drops of $1 \%$ aqueous uranyl acetate (25). Also, the procedure of Brlansky and Derrick (5) was used for trapping. Coated grids were floated on the appropriate antiserum drops (control grids were floated on normal rabbit serum) diluted 1:1,000 with Tris buffer (0.05 M, pH 7.2) for 15 to $30 \mathrm{~min}$ at room temperature. Unabsorbed serum was removed by floating the grids for $5 \mathrm{~min}$, or washing with 40 drops of Tris buffer. Experimental grids were immediately floated on crude sap extracts for 30 to 45 min. Following the reaction, the grids were washed to remove plant debris by floating 3 to $5 \mathrm{~min}$ or washing with 40 drops of distilled water. Then grids were stained with $1 \%$ uranyl acetate and examined with Phillips TEM 301G electron microscope.

Seed assays. To investigate the incidence of transmission through seed of important seed-borne viruses in commercial soybean seeds as potential primary inoculum sources, 15 soybean seed production fields in Mazandaran and Golestan provinces, the major sites of seed production in Iran, were visited in early autumn of 2000, and 7,830 soybean seeds were collected randomly $(4,210$ and 3,620 seeds, respectively). During 1 month, seed (cvs. Gorgan 3, Hill, Sahar, and Williams) were planted in groups of 10 in plastic pots containing pasteurized soil and maintained in a glasshouse with at least $12 \mathrm{~h}$ light, 25 $\pm 5^{\circ} \mathrm{C}$, and 50 to $70 \%$ relative humidity. A total of 7,152 seedlings were tested individually by DAS-ELISA at the fourtrifoliate-leaf stage for the presence of seed transmissible viruses. In addition, one isolate of SMV from Mazandaran Province (SMV-Mz) was selected to evaluate seed coat mottling and seed transmission. Thirty soybean plants (cv. Williams) were inoculated with SMV-Mz 16 days after planting. Systemically infected plants were kept in a greenhouse, and the harvested seeds were tested for SMV transmission as above.

\section{RESULTS}

Surveys. Results of cross-reactivity assays indicated that there was no cross reaction among the detection systems of related viruses in the nepovirus or potyvirus groups except PeMoV and BlCMV raw antiserum, which had a weak reaction with SMV, and BCMV and BYMV positive controls, respectively. ELISAs with random soybean leaf samples showed that the highest incidence of virus infection occurred in Mazandaran (18.6\%), followed by Golestan (15.7\%), Khuzestan (14.2\%), Ardabil (13.9\%), and Lorestan (13.5\%). Viral disease incidence in decreasing order was SMV (13.3\%), TSWV (5.4\%), TRSV $(4.2 \%)$, TSV (4.1\%), PEMV (2.9\%), BYMV (2.2\%), ToRSV (2.1\%), AlMV (1.3\%), BCMV (0.8\%), and CMV (0.6\%) with the overall incidence of $15.7 \%$. Furthermore, $48(1.5 \%)$ soybean leaf samples had positive reaction in ELISA with TMV antisera. Of 195 leaves exhibiting PSF, $4.1 \%$ of the samples were infected with SMV, followed by TRSV (2.6\%), ToRSV (2.1\%), TSV (2.1\%), TSWV $(0.5 \%)$, BYMV $(0.5 \%)$, and PEMV $(0.5 \%)$. In other words, $7.2 \%$ (14) of them had viral infection (Table 3).

Field symptoms associated with virus infection included: mosaic, mottling, crinkle, vein clearing, and vein necrosis with SMV; mosaic and mottling with AlMV, BCMV, BICMV, BYMV, PEMV, PeMoV, and TMV; top necrosis in most TRSV- and ToRSV-infected plants; and chlorosis and necrosis with TSWV. However, plants were frequently infected with more than one virus, so it was not possible to correlate specific symptoms with a particular virus. In this study, all 13 viruses were detected in samples, although number and relative incidence of individual viruses reported in the five main areas differed (Table 3). AlMV, PEMV, SMV, TRSV, TSV, and TSWV were detected in all provinces surveyed. BlCMV was detected in Mazandaran and Lorestan, and PeMoV in Golestan, but only in the symptomatic samples; the randomly collected ones were not tested for these two viruses.

Host range studies and electron microscopy. Although suitable for detection,

Table 2. Reaction of selected indicator plant species to different viruses that infect soybean ${ }^{\mathrm{a}}$

\begin{tabular}{|c|c|c|c|c|c|c|c|c|c|c|c|c|}
\hline \multirow[b]{2}{*}{ Indicator plant } & \multicolumn{12}{|c|}{ Virus } \\
\hline & AlMV & BCMV & BICMV & BYMV & CMV & PEMV & PeMoV & SMV & TRSV & ToRSV & TSV & TSWV \\
\hline $\begin{array}{l}\text { Amaranthaceae } \\
\text { Gomphrena } \\
\text { globosa }\end{array}$ & $-\mathrm{b} * \mathrm{c}$ & $-*$ & ND & $-\dagger *$ & $\mathrm{~S}$ & - & - & - & ND & ND & $\mathrm{NLL}^{1}$ & NLL, SN \\
\hline $\begin{array}{l}\text { Chenopodiaceae } \\
\text { Chenopodium } \\
\text { amaranticolor }\end{array}$ & CLL & $-*$ & $\mathrm{CLL}^{1}$ & $\mathrm{NLL}^{1}$ & NLL & $\mathrm{NLL}^{1}$ & - & - & $\mathrm{NLL}^{1}$ & CLL, SN & ND & NLL \\
\hline C. quinoa & $\mathrm{CLL}^{1}$ & $-\dagger *$ & CLL & NLL* & NLL & CLL & - & CLL & NLL & CLL, SN & ND & NLL \\
\hline $\begin{array}{l}\text { Cucurbitaceae } \\
\text { Cucumis sativus }\end{array}$ & ND & - & - & - & Mos & ND & $-*$ & - & CLL, Mot & CLL, Chl ${ }^{1}$ & ND & CLL \\
\hline $\begin{array}{l}\text { Fabaceae } \\
\text { Arachis hypogaeg }\end{array}$ & ND & ND & - & - & - & ND & $\mathrm{Mot}^{\mathrm{p}}$ & _- & ND & ND & Chl & Mos SN \\
\hline $\begin{array}{l}\text { Glycine max } \\
\text { cv. Hill }\end{array}$ & Mos & Mos & Mos & ND & Mos & Mos & Mot & $\operatorname{Mos}^{p}$ & SN & SN & Chl & Chl, SN \\
\hline G. $\max$ cv. Sahar & Mos & Mos & Mot & Mos & Mos & Mos & Mot & Mos & ND & SN & Chl & Chl, SN \\
\hline $\begin{array}{l}\text { Phaseolus vulgaris } \\
\text { cv. Topcrop }\end{array}$ & NLL & $\operatorname{Mos}^{p}$ & - & Mos & NLL & ND & $\mathrm{NLL}^{1 *}$ & $N_{L} L^{1}$ & NLL, SN & CLL, SN & $\mathrm{ND}$ & NLL \\
\hline Pisum sativum & ND & ND & - & Mos & ND & Mos, En ${ }^{p}$ & Mot & $-*$ & ND & ND & ND & $-*$ \\
\hline Vicia faba & NLL & $-*$ & - & $\operatorname{Mos}^{p}$ & $\mathrm{NLL}^{1}$ & Mos & - & - & ND & ND & ND & NLL* \\
\hline $\begin{array}{l}\text { Vigna unguiculata } \\
\text { cv. Mashad }\end{array}$ & NLL & $-*$ & CLL, $\operatorname{Mos}^{p}$ & $-*$ & NLL & - & $-*$ & $-*$ & CLL, SN & CLL, SN & $-*$ & NLL, StN ${ }^{1}$ \\
\hline Solanaceae & & & & & & & & & & & & \\
\hline Datura metel & ND & - & - & - & ND & ND & - & - & ND & ND & - & Mos, SN \\
\hline $\begin{array}{l}\text { Nicotiana } \\
\text { benthamiana }\end{array}$ & ND & $-*$ & Mos & Mos & ND & ND & ND & ND & ND & ND & $-*$ & SN \\
\hline N. glutinosa & S & - & - & $-*$ & $\operatorname{Mos}^{p}$ & - & - & - & ND & ND & $-*$ & NLL, SN* \\
\hline N. rustica & $\operatorname{Mot}^{p}$ & - & - & $-*$ & Mos & - & - & - & ND & ND & $\mathrm{SN}^{*}$ & CLL, $\mathrm{SN}^{p}$ \\
\hline $\begin{array}{l}\text { N. tabacum } \\
\text { cv. Samsun }\end{array}$ & CLL, S & - & - & $-*$ & Mos & - & - & - & NLL, $\operatorname{Mot}^{p^{\dagger}}$ & $\mathrm{RS}, \mathrm{Chl}^{\mathrm{p}}$ & $\mathrm{SN}^{\mathrm{p}}$ & Chl, SN \\
\hline
\end{tabular}

\footnotetext{
${ }^{a}$ Enzyme-linked immunosorbent assay (ELISA) used for the presence of each virus in indicator host plants.

$\mathrm{b}_{-}=$no reaction (when tested by ELISA and also no visible symptoms), $\mathrm{CLL}=$ chlorotic local lesion, $\mathrm{Chl}=$ chlorosis, En $=$ enation, Mos $=$ mosaic, Mot $=$ mottling, $\mathrm{ND}=$ not determined, $\mathrm{NLL}=$ necrotic local lesion, $\mathrm{RS}=$ ring spot, $\mathrm{S}=$ systemic (symptomless), $\mathrm{SN}=$ systemic necrosis, $\mathrm{StN}=$ stem necrosis . $\mathrm{c} *=$ different from other reports (6). ${ }^{\dagger}=$ not identical to AAB Descriptions of Plant Viruses. ${ }^{1}=$ local lesion host. $\mathrm{p}^{\mathrm{p}}=$ propagative host.
} 
biological assays or electron microscopy (EM) are not generally sufficient for identification of the viruses. In this study, we used EM and tested different plant species for detection of soybean viruses to confirm serological diagnoses. The host ranges and symptoms observed in this study for all of these viruses were generally in line with those reported by others (6), but with some differences (Table 2). The respective virus particles in selected samples that tested positive by ELISA were observed by EM or after being trapped by their specific antisera. Our BCMV isolates did not systemically infect Vicia faba and Pisum sativum, or produce local infection on Chenopodium amaranticolor as reported for this virus (27). BYMV has a much wider host range (3), and the soybean isolates infected $P$. sativum, V. faba, and C. amaranticolor. In contrast, the BlCMV readily gave systemic reactions in Vigna unguiculata identical to those described previously (31). SMV isolates in this study were transmitted through soybean seed and failed to cause systemic symptoms in Phaseolus vulgaris cv. Topcrop, V. faba, and V. unguiculata (4). The PeMoV isolates induced mottling in Arachis hypogaea and P. sativum, which differs from the four previously mentioned viruses (2). These viruses had flexuous particles with about 740 to $750 \mathrm{~nm}$, characteristic of the family Potyviridae. Host range and particles (c. 100 $\mathrm{nm}$ ) of the Tospovirus isolated from soybean in Mazandaran were similar to those described for TSWV (17). Characteristic symptoms were observed for PEMV in different indicator hosts, including mosaic and enation in $P$. sativum. In addition, PEMV had small polyhedral particles of 28 to $30 \mathrm{~nm}$, which are typical for this virus (36). Host range and symptoms of AlMV and CMV isolated from soybean were identical to previous reports; however, these viruses had bacilliform and spherical particles, respectively $(18,28)$. Although the symptoms of TSV in diagnostic hosts were similar to those previously reported, they may vary and may be confused with those of other viruses, and identification should be made by serologi- cal assays (33). We observed differences in reaction of TRSV and ToRSV on Chenopodium quinoa and C. amaranticolor similar to those described previously. Differential host reactions are useful for distinguishing isolates of the two viruses, but such tests are not reliable for detection of all isolates. Serological tests are essential for positive identification of isolates that are thought to belong to viruses in the Nepoviridae $(37,38)$. Additionally, inoculation of soybean plants with the studied viruses did not result in characteristic symptoms of PSF.

Seed transmission. Overall, $8 \%$ of seed collected from Golestan and Mazandaran transmitted seed-borne viruses to germinated soybean seedlings, $7.1 \%$ from Golestan and $8.9 \%$ from Mazandaran. According to these data, $5.3 \%$ of collected soybean seeds transmitted SMV followed by TSV $(2.3 \%)$, TRSV $(2.1 \%)$, and ToRSV (1.4\%) (Table 4). About $24 \%$ of these seeds were discolored. Also, $93.2 \%$ of seed from soybean plants (cv. Williams) that were inoculated with SMV-Mz showed seed-coat mottling, whereas only $7.4 \%$ transmitted SMV through seeds.

\section{DISCUSSION}

Prior to 1996, the literature on the natural occurrence of viruses infecting soybean in Iran was limited to SMV $(8,20)$, TRSV, ToRSV, and TSV (32). Based on these results, we showed incidence and distribution of 13 viruses in soybean fields of Iran, of which SMV, other seed-transmissible viruses, and TSWV usually were the most prevalent. High incidences of SMV were recorded in all soybean producing regions. This virus can significantly reduce soybean yields, and yield losses as high as 50\% have been reported (42).

In this survey, samples were collected during the growing seasons from July through September of 1999 and 2000. Viruses were detected in most fields, but some provinces had higher incidences of virus infections than others. However, significant differences in incidences were observed among fields in the same province. It seems that in a particular province, presence of an inoculum source, especially infected seeds, was more important to incidence of virus infection than the field's location. Virus incidence in large fields, which were planted with certified seeds, was lower than that in small fields grown with uncertified seeds (e.g., up to $100 \%$ in a field in Mazandaran) in each province. Seed-borne viruses were more prevalent than non-seed-borne viruses in the surveyed provinces. The results indicated that the relative incidence of viruses that are transmitted only by aphids was less than that of viruses that either have two modes of transmission (SMV, TRSV, ToRSV, and TSV) or are spread by thrips (TSWV), as shown in Table 3 . The possible reason for the high incidence of TSWV may be the extremely wide host range of this virus, which can infect more than 1,000 plant species (23). High populations of Thrips tabaci Lindeman were observed in soybean fields infected with TSWV. In ELISA, Tospovirus infection of trapped thrips was detected (data not shown).

Based on serological reactivity and nucleotide sequence data, BlCMV is now considered a strain of BCMV $(6,41)$, which may explain why these two viruses cross reacted in ELISA. However, our

Table 4. Percentage of germinated seedlings infected with virus from seed from Golestan and Mazandaran provinces in Iran

\begin{tabular}{lccccc}
\hline & \multicolumn{5}{c}{ Viruses } \\
\cline { 2 - 5 } Province & SMV & TRSV & ToRSV & TSV & Total IS $^{\mathbf{a}}$ \\
\hline Golestan & 4.7 & 2.7 & 1.3 & 3.0 & 7.1 \\
Mazandaran & 5.8 & 1.6 & 1.4 & 1.7 & 8.9 \\
Total IS & 5.3 & 2.1 & 1.4 & 2.3 & 8.0 \\
\hline
\end{tabular}

${ }^{\text {a }}$ IS = infected seedlings.

Table 3. Incidence (\%) of virus infection of soybean in different provinces of Iran

\begin{tabular}{|c|c|c|c|c|c|c|c|c|c|c|c|c|c|c|}
\hline \multirow[b]{2}{*}{ Province } & \multicolumn{14}{|c|}{ Viruses } \\
\hline & $\overline{\text { AIMV }}$ & BCMV & BICMV & BYMV & CMV & PEMV & PeMoV & SMV & TMV & TRSV & ToRSV & TSV & TSWV & Total \\
\hline Ardabil & 0.9 & 0.0 & $\mathrm{n}^{\mathrm{a}}$ & 3.8 & 0.5 & 4.5 & $\mathrm{n}$ & 9.6 & 1.1 & 2.7 & 0.0 & 2.2 & 2.9 & 13.9 \\
\hline Golestan & 1.7 & 0.7 & $\mathrm{n}$ & 2.7 & 0.0 & 4.2 & $t^{\mathrm{b}}$ & 14.1 & 0.0 & 5.9 & 1.8 & 6.5 & 7.3 & 15.7 \\
\hline Khuzestan & 2.0 & 2.0 & $\mathrm{n}$ & 2.2 & 1.6 & 3.8 & $\mathrm{n}$ & 12.9 & 2.7 & 4.7 & 3.1 & 2.2 & 2.2 & 14.2 \\
\hline Lorestan & 1.1 & 1.5 & + & 0.0 & 0.0 & 2.1 & $\mathrm{n}$ & 12.4 & 3.0 & 1.5 & 2.6 & 3.9 & 5.4 & 13.5 \\
\hline PSF & $0.0^{\mathrm{c}}$ & 0.0 & 0.0 & 0.0 & 0.0 & 1.2 & 0.0 & 3.7 & 0.0 & 2.5 & 1.2 & 2.5 & 0.0 & 7.4 \\
\hline Mazandaran & 1.0 & 0.5 & + & 1.8 & 1.1 & 1.0 & $\mathrm{n}$ & 15.5 & 1.7 & 4.8 & 2.9 & 4.3 & 6.9 & 18.6 \\
\hline PSF & 0.0 & 0.0 & 0.0 & 0.9 & 0.0 & 0.0 & 0.0 & 4.4 & 0.0 & 2.6 & 2.6 & 1.8 & 0.9 & 7.0 \\
\hline Overall & 1.3 & 0.8 & $\mathrm{n}$ & 2.2 & 0.6 & 2.9 & $\mathrm{n}$ & 13.3 & 1.5 & 4.2 & 2.1 & 4.1 & 5.4 & 15.7 \\
\hline PSF & 0.0 & 0.0 & 0.0 & 0.5 & 0.0 & 0.5 & 0.0 & 4.1 & 0.0 & 2.6 & 2.1 & 2.1 & 0.5 & 7.2 \\
\hline
\end{tabular}

${ }^{\mathrm{a}} \mathrm{n}=$ not determined (samples were not tested for a specific virus).

${ }^{\mathrm{b}}+=$ infection detected (samples were not assayed to determine an incidence value).

${ }^{c}$ Incidence of viruses in samples showing pod set failure syndrome (PSF). 
results from serological cross reactivity and host ranges showed a probable relationship between BCMV and BlCMV, but are not sufficient to support the change in nomenclature.

PeMoV was first reported on peanut (Arachis hypogaea L.) from Golestan (34). This virus is transmitted in a nonpersistent manner by several aphids, and the incidence of seed transmission is up to $8 \%$ in some peanut genotypes $(2,39)$. High similarities in host ranges of $\mathrm{PeMoV}$ isolates collected from peanut and soybean fields of Golestan indicate a probable common origin of the viruses, but this hypothesis will need to be confirmed with molecular evidence.

Host ranges of different tospovirus isolates collected from Golestan, Mazandaran, and Lorestan provinces were similar, but considerable differences were found in the symptoms induced and their capacity to infect different plant species (13). It seems that other tospoviruses may be present in soybean fields of Iran, which could be confirmed using monoclonal antibodies and molecular characterization. In recent years, Tospovirus infections have been reported frequently in other crops $(12,14,26,30,35)$. TSWV and Impatiens necrotic spot virus are important emerging viruses in many parts of the world and may be of increasing importance in areas where soybean is grown (15). Furthermore, Groundnut bud necrosis virus and Groundnut ringspot virus, genus Tospovirus, have been reported to infect soybean naturally in South Africa and India, respectively $(29,40)$. Nevertheless, there are few recent reports on Tospovirus infections of soybean.

A new strain of TMV was isolated in Yugoslavia from naturally infected soybean plants exhibiting vein clearing and mild mosaic symptoms and also was reported in Romania. Information on the incidence of the soybean strain (TMV-S) or disease severity is unknown. In recent soybean surveys in the United States, a virus was detected that reacted positively in ELISA to Sunn-hemp mosaic virus, a bean-infecting tobamovirus. The relationship between this virus and TMV-S is not known. In ELISA with polyclonal antisera, TMV-S is more closely related to the common strain of TMV than to legume infecting strains $(15,24)$. In our studies, $1.5 \%$ (48) of randomly collected leaf samples had positive reaction in ELISA with antiserum to the common strain of TMV, indicating the possible infection of soybeans in Iran with a Tobamovirus, which is serologically related to TMV. However, additional studies are necessary to confirm the presence of TMV.

When soybean plants were inoculated with the viruses tested, none produced symptoms characteristic of PSF. Since no correlation was observed between PSF and presence of the 13 viruses tested, the in- volvement of other viruses or factors in this syndrome is suggested, which differs from a previous report (32).

Results showed that overall incidence of seed-transmissible viruses in random leaf samples of Golestan and Mazandaran, including SMV, TRSV, ToRSV, and TSV, was $14.9,5.3,2.4$, and $5.2 \%$, respectively (Table 3). Comparison of these data with incidence of seed-borne viruses in collected seed samples (Table 4), in which SMV was the highest (5.3\%), followed by TSV (2.3\%), TRSV (2.1\%), and ToRSV (1.4\%), indicates the importance of soybean seed health management in the control of these seed-borne viruses. The results from our seed assays indicated that plants infected with SMV produced seed coat mottling, whereas noninoculated plants produced little or no mottled seed as reported by Hobbs et al. (16).

This survey revealed natural occurrence and infections of AlMV, BCMV, BlCMV, BYMV, CMV, PEMV, PeMoV, and TSWV, and probable incidence of a Tobamovirus serologically related to TMV, in soybean fields of Iran. AlMV, BCMV, BYMV, CMV, PEMV, PeMoV, TMV, and TSWV have been previously reported from other hosts in Iran $(14,19,21,30,34)$ that may play roles as alternative hosts for soybean crops. This survey was restricted to five main soybean-growing areas and to two growing seasons. An extension of this survey to other areas of Iran may reveal the presence of more viruses and viral strains in this crop. Soybean is exposed naturally to many virus infections with different modes of transmission (15). Therefore, several protective measures, such as use of resistant or tolerant varieties, use of healthy seed for the control of seed-borne viruses, removal of sources of infection in or around fields, use of a fallow period for host crops to break the infection cycle, and spraying crops with insecticide to control the insect vectors, should be employed to reduce the level of virus infection.

\section{ACKNOWLEDGMENTS}

We thank the Plant Virology Department of Plant Pests and Diseases Research Institute (PPDRI), Science and Research Campus of Islamic Azad University, and Oilseed Research and Development Company that supported this research. The research was mainly supported by Plant Virology Department of PPDRI. We thank S. Winter (DSMZ, Braunschweig Germany), G. Thottappilly (ITIA, Ibadan, Nigeria), and J. Chalkey (University of Georgia, Agricultural College Experimental Station, USA) for kindly providing some of the antisera and positive samples that were used in this study. Also, we thank K. M. Makkouk (ICARDA, Syria) and A. Mahmoudpour (Tabriz University, Iran) for their kind advice.

\section{LITERATURE CITED}

1. Banttari, E. E., and Goodwin, P. H. 1985. Detection of potato viruses $\mathrm{S}, \mathrm{X}$, and $\mathrm{Y}$ by enzyme-linked immunosorbent assay on nitrocellulose membranes (Dot-ELISA). Plant Dis. 62:202-205.

2. Bock, K. R., and Kuhn, C. W. 1975. Peanut mottle virus. AAB Descriptions of Plant $\mathrm{Vi}$ ruses, No. 141

3. Bos, L. 1970. Bean yellow mosaic virus. AAB Descriptions of Plant Viruses, No. 40.

4. Bos, L. 1972. Soybean mosaic virus. AAB Descriptions of Plant Viruses, No. 93.

5. Brlansky, R. H., and Derrick, K. S. 1979. Detection of seedborne plant viruses using serologically specific electron microscopy. Phytopathology 69:96-100.

6. Brunt, A. A., Crabtree, K., Dallwitz, M. J., Gibbs, A. J., and Watson, L. 1995. Viruses of plants, description and lists from the VIDE database. CAB International, Wallingford, UK.

7. Clark, M. F., and Adams, A. N. 1977. Characteristics of the microplate method of enzymelinked immunosorbent assay for the detection of plant viruses. J. Gen. Virol. 34:475-483.

8. Eskandari, F. 1978. Studies on soybean mosaic in Iran. Z. Pflanzenkrankh. Pflanzenschutz 85:686-688.

9. FAO. 2001. FAO production yearbook 1999 Vol. 53, Rome.

10. Farzadfar, Sh., Golnaraghi, A. R., and Pourrahim, R. 2002. Plant viruses of Iran. (In English.) Saman Co., Tehran, Iran.

11. Farzadfar, Sh., and Izadpanah, K. 2001. Sources and properties of the Iranian isolate of Pea enation mosaic virus. Iran. J. Plant Pathol. 37:77.

12. Golnaraghi, A. R., Pourrahim, R., Shahraeen, N., and Farzadfar, Sh. 2002. First report of Groundnut bud necrosis virus in Iran. Plant Dis. 86:561.

13. Golnaraghi, A. R., Shahraeen, N., Pourrahim, R., and Farzadfar, Sh. 2002. Comparative host reactions of three Tomato spotted wilt Tospovirus isolates from soybean in Iran. Page 119 in: Proc. Iranian Congr. Virol., 1st.

14. Golnaraghi, A. R., Shahraeen, N., Pourrahim, R., Ghorbani, Sh., and Farzadfar, Sh. 2001. First report of a Tospovirus infection of peanuts in Iran. Plant Dis. 85:1286.

15. Hartman, G. L., Sinclair, J. B., and Rupe, J. C. 1999. Compendium of Soybean Diseases. 4th ed. American Phytopathologial Society, St. Paul, MN.

16. Hobbs, H. A., Hartman, G. L., Wang, Y., Hill, C. B., Bernard, R. L., and Pederson, W. A. 2003. Occurrence of seed coat mottling in soybean plants inoculated with Bean pod mottle virus and Soybean mosaic virus. Plant Dis. 87:1333-1336.

17. Ie, T. S. 1970. Tomato spotted wilt virus. AAB Descriptions of Plant Viruses, No. 39.

18. Jaspars, E. M. J., and Bos, L. 1980. Alfalfa mosaic virus. AAB Descriptions of Plant Viruses, No. 229.

19. Kaiser, W. J., Mossahebi, G. H., and Okhovat, M. 1971. Alternate hosts of viruses affecting food legumes in Iran. Iran. J. Plant Pathol. 7:85.

20. Karimi, A., and Noaparast, F. 1989. Soybean mosaic virus in Iran. Page 171 in: Proc. Plant Prot. Congr. Iran, 9th.

21. Koohi-Habibi, M., and Rahimian, H. 1993 Detection of tobacco and cucumber mosaic viruses in tobacco fields by gel-electrophoresis of crude leaf extracts. Page 172 in: Proc. Plant Prot. Congr. Iran, 11th.

22. Lister, R. M. 1978. Application of the enzymelinked immunosorbent assay for detecting viruses in soybean seed and plants. Phythopathology 68:1393-1400.

23. Maris, P. C., Jossten, N. N., Goldbach, R. W., and Peters, D. 2003. Restricted spread of Tomato spotted wilt virus in thrips-resistant pepper. Phytopathology 93:1223-1227.

24. McDaniel, L. L., Maratos, M. L., Goodman, J. E., and Tolin, S. A. 1995. Partial characterization of a soybean strain of tobacco mosaic virus. Plant Dis. 79:206-211.

25. Milne, R. G., and Lesemann, D. E. 1984. Immunosorbent electron microscopy in plant 
virus studies. Pages 85-101 in: Methods in Virology. Vol. III. K. Maramorosch and H. Koprowski, eds. Academic Press, New York.

26. Moini, A. A., and Izadpanah, K. 2001. Report of Impatiens necrotic spot virus infection of tobacco in Iran. Iran. J. Plant Pathol. 37:93.

27. Morales, F. J., and Bos, L. 1988. Bean common mosaic virus. AAB Descriptions of Plant Viruses, No. 337.

28. Palukaitis, P., and Garcia-Arenal, F. 2003. Cucumber mosaic virus. AAB Descriptions of Plant Viruses, No. 400.

29. Pietersen, G., and Morris, J. 2002. Natural Occurrence of Groundnut ringspot virus on soybean in South Africa. Plant Dis. 86:1271.

30. Pourrahim, R., Farzadfar, Sh., Moini, A. A., Shahraeen, N., and Ahoonmanesh, A. 2001. First report of Tomato spotted wilt virus on potatoes in Iran. Plant Dis. 85:442.

31. Purcifull, D., and Gonsalves, D. 1985. Blackeye cowpea mosaic virus. AAB Descriptions of Plant Viruses, No. 305

32. Rahimian, H., Hamdollah-Zadeh, A., and
Montazeri, M. 1995. Viruses associated with soybean pod set failure syndrome in Iran. Iran. J. Plant Pathol. 32:70-71.

33. Scott, S. W. 2001. Tobacco streak virus. AAB Descriptions of Plant Viruses, No. 381.

34. Shahraeen, N., and Bananej, K. 1995. Occurrence of peanut mottle virus in Gorgan province. Page 110 in: Proc. Iranian Plant Prot. Congr., 12th.

35. Shahraeen, N., Ghotbi, T., and Mehraban, A. H. 2002. Occurrence of Impatiens necrotic spot virus in ornamentals in Mahallat and Tehran Provinces in Iran. Plant Dis. 86:694.

36. Skaf, J. S., and de Zoeten, G. A. 2000. Pea enation mosaic virus. AAB Descriptions of Plant Viruses, No. 372.

37. Stace-Smith, R. 1984. Tomato ringspot virus. AAB Descriptions of Plant Viruses, No. 290.

38. Stace-Smith, R. 1985. Tobacco ringspot virus. AAB Descriptions of Plant Viruses, No. 309.

39. Sutic, D. D., Ford, R. E., and Tosic, M. T. 1999. Handbook of Plant Virus Diseases. CRC Press, Boca Raton, FL.
40. Thakur, M. P., Reddy, D. V. R., Reddy, A. S Ratna, A. S., Al-Nasiri, M., and Agrawal, K. C. 1996. Identification of bud blight of soybean (Glycine $\max (\mathrm{L}$.$) Merr.) through ELISA and$ infectivity assay. Indian J. Virol. 12:79-82.

41. van Regenmortel, M. H. V., Fauquet, C. M., Bishop, D. H. L., Carstens, E. B., Estes, M. K., Lemon, S. M., Maniloff, J., Mayo, M. A. McGeoch, D. J., Pringle, C. R., and Wickner, R. B., eds. 2000. Virus Taxonomy: Classification and Nomenclature of Viruses, 7th Report of the International Committee on Taxonomy of Viruses. Academic Press, New York.

42. Wang, R. Y., and Ghabrial, S. A. 2002. Effect of aphid behavior on efficiency of transmission of Soybean mosaic virus by the soybeancolonizing aphid, Aphis glycines. Plant Dis. 86:1260-1264.

43. Wrather, J. A., Koenning, S. R., and Anderson, T. R. 2003. Effect of diseases on soybean yields in the United States and Ontario (1999 2002). Online. Plant Health Progress doi:10.1094/PHP-2003-0325-01-RV. 